\title{
Climate Change Adaptation Strategies Among Cereal Farmers in Kwara State, Nigeria
}

\author{
S. A. Aderinoye-Abdulwahab and T. A. Abdulbaki
}

\section{Contents}

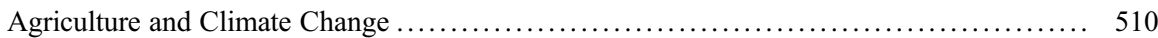

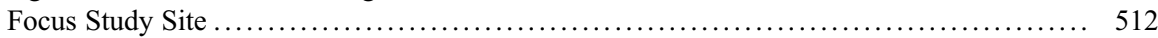

Agriculture and Cereal Production in Nigeria .................................. 513

The Impact of Climate Variability on Agriculture in Nigeria ...................... 514

Climate Change Adaptation Strategies for Cereal Farmers in Nigeria .................. 516

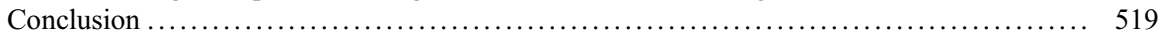

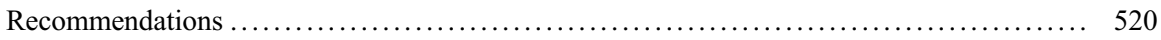

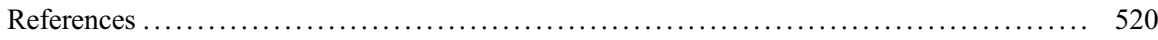

\section{Abstract}

Agriculture is the art and science of food production which spans soil cultivation, crop growing, and livestock rearing. Over the years, it has served as a means of employment and accounts for more than one-third of total gross domestic product. Cereals, which include rice, maize, and sorghum, are the major dietary energy suppliers and they provide significant amounts of protein, minerals (potassium and calcium), and vitamins (vitamin A and C). The growth and good yield of cereal crop can be greatly influenced by elements of weather and climate such as temperature, sunlight, and relative humidity. While climate determines the choice of what plant to cultivate and how to cultivate, it has been undoubtedly identified as one of the fundamental factors that determine both crop cultivation and

\footnotetext{
This chapter was previously published non-open access with exclusive rights reserved by the Publisher. It has been changed retrospectively to open access under a CC BY 4.0 license and the copyright holder is "The Author(s)". For further details, please see the license information at the end of the chapter.
}

\footnotetext{
S. A. Aderinoye-Abdulwahab $(\bowtie) \cdot T$. A. Abdulbaki

Department of Agricultural Extension and Rural Development, Faculty of Agriculture, University of Ilorin, Ilorin, Nigeria

e-mail: aderinoye.as@unilorin.edu.ng
} 
livestock keeping. The chapter, though theoretical, adopted Kwara State, Nigeria, as the focus due to favorable weather conditions that support grains production. It was observed that the effect of climate change on cereal production includes: drastic reduction in grains production, reduction in farmers' profit level, increment in cost during production, diversification to nonfarming activities, and discouragement of youth from participating in agricultural activities. Also, the adopted coping strategies employed by farmers in the focus site were early planting, planting of improved variety, irrigation activities, alternates crop rotation, and cultivation of more agricultural areas. The chapter thus concluded that climate change has negative impact on cereals production and recommends that government should provide communal irrigation facilities that will cushion the effect of low rains on farmers' productivity, while early planting and cultivation of drought-resistant cultivars should be encouraged.

\section{Keywords}

Grains $\cdot$ Crop rotation $\cdot$ Early planting $\cdot$ Irrigation $\cdot$ Yield

\section{Agriculture and Climate Change}

Our ancestors advanced from being hunter gatherers to live a more settled lifestyle since about a thousand years ago, residing in one place for a lengthy period rather than living a nomadic lifestyle. This change happened concurrently with the taming of different species of plants and animals, which were bred, kept or planted in close proximity rather than hunted. Over the periods, agriculture continued to advance although, up until the twentieth century, most of the work were undertaken by mankind and animals rather than machines. Such fauna and flora activities (which could also be natural), including human's method of cultivation as well changes in weather and climate, left the environment in a tough situation that we now refer to as climate change and its impact. Agriculture is largely reliant on weather and climate, hence climatic factors such as rainfall, sunlight, airstream, and temperature influence the distribution and productivity of crops (Sokoto et al. 2016).

Of all human endeavors, agriculture remains one of the most demanding on land. Land is thus in constant short supply given the effects of biophysical factors such as rain, temperature, and topography of an area, as well as unsustainable land management practices which include deforestation, uncontrolled soil nutrient mining, and cultivation on steep slopes (FAO 2015). The implication of such effects on land may comprise overgrazing, desertification, soil erosion, deforestation, among others and all of these further translate into shortage of land for human's endeavors. Perhaps the continued presence of these effects is one of the reasons why scholars have maintained that the ozone layer may eventually be depleted given that the earth is warming up (IPCC 2007; Mboera et al. 2012; FAO 2015) as a result of people's activities which enable greenhouse gases (GHG) like methane, water vapor, nitrous oxide, and carbon dioxide to trap heat into space. 
Climate, a manifestation of weather and other atmospheric conditions, has largely been acknowledged as one of the fundamental indicators that determine both crop cultivation and livestock keeping. It is a long-term average weather conditions that directly or indirectly impact the events that play out on farms. Climatic conditions of any environment govern the choice of crop and how they will be planted, as well as the yields and nature of livestock to keep in a given location. This statement is alluded to in the work of Ajadi et al. (2011) where it was similarly shown that biophysical factors such as sunlight energy, temperature, humidity, and other climatic variables determine the global distribution and yield of crops and livestock. On the other hand, climate change is the long-term change in average temperature as a result of the earth's warming which may eventually translate into the depletion of the ozone layer. Although, an inconsistent phenomenon, climate change points clearly at threats to the future of people through the depletion of the ozone layer, thereby negatively impacting on all segments of human endeavor, agriculture inclusive. As a result of human and natural activities that release greenhouse gases (GHG) which had hitherto trapped heat within the atmosphere (Mboera et al. 2012), higher concentrations of these gases in the atmosphere leads to the earth's warming. These human activities could include but not limited to: use of fossil fuel, land use change, and agriculture (IPCC 2007; Mboera et al. 2012; Omumbo et al. 2011). Many people in developed regions prefer to assume that climate change is not real than to prepare to adjust their living standards to suit the effect of climate change (Mboera et al. 2012). Hence, there is a need to increase farmers' awareness on the effect of climate change as well as adequately prepare for its mitigation. Researches to proffer ease of living with climate change and its impact are therefore expedient.

It has equally been shown in another instance that the planet's temperature is increasing, leading to frequent changes in rainfall patterns and extreme events such as droughts (Zoellick 2009). The International Panel of Climate Change (IPCC 2007) also submitted that agriculture, forestry, and the change in land use, account for up to $25 \%$ of human induced GHG emissions while agriculture is the chief source of released methane and nitrous oxide, bearing in mind that these two gases constitute the substantial part of GHGs. Similarly, Odjugo (2010) stated that climate change is undeniable and its impacts are clearly seen in rising temperatures, low rainfalls, desertification, water scarcity, health, and agricultural problems. It has also been reported that several million hectares of crops and livestock have been destroyed due to climate-induced tragedies (FAO 2015). Climate change has therefore impacted on the economy of nations so much so that agriculture sector absorbs about $22 \%$ of the entire damage in developing countries (FAO 2015). Therefore, there is a dire need for farmers to be aware of the extent of destruction that the impact of climate change can constitute in their livelihoods as this will work to boost their preparedness for its mitigation. Reuben and Barau (2012) had similarly reported that incidences of low humidity during propagative stage will definitely result in poor yields of crops while the Food and Agriculture Organization (FAO) also poised that the crop sector is the most affected during unfavorable weather episodes (FAO 2015).

It is imperative to note that countries would feel the impact of climate change differently; while the effect may be positive in some areas, other climes might be 
negatively affected. Some additional degree of climate change and its impact is unavoidable regardless of the amount of measures put in place to ameliorate or forestall it. As such, there is an inevitable need to adapt farming to resilient conditions of agricultural systems. The two major means of reducing climate impact are mitigation and adaptation. Adapting agriculture to climate change and sustaining adequate food production could help to resolve the current glitches. However, with growing levels of GHGs, climate change and its consequences will continue to pose new challenges as well as mete out untold hardship on people. Currently, agriculture (and related sectors) contributes about a quarter of human-induced GHG emissions (IPCC 2007; FAO 2015), so it is highly necessary to reduce these emissions and other unfavorable effects from our environment. Many times, decreasing resource inputs and increasing efficacy goes hand in hand with mitigating emissions. If we can reduce the concentration of GHGs in our atmosphere, then extreme climate circumstances in the future would have been reduced considerably, and thus, it will be easier to adapt to climate change.

This chapter will therefore dwell on the interconnectedness of agriculture, climate change, and the effects of climate change on grain production. It will as well highlight grain farmers' coping and adaptation strategies to the impact of climate change.

\section{Focus Study Site}

Kwara State is located in a hot and humid region with two major seasons; it has tropical wet and dry climate (Olanrewaju 2009), each lasting for about 6 months. Kwara State has an annual rainfall range of 1000-1500 mm from March until early September, although this is gradually shifting forward due to climate variations; while the dry season used to be from October to March. Again, this is also on the moving trend as temperature continues to be on the high side up until April/May. Temperature is uniformly high and ranges between $25^{\circ} \mathrm{C}$ and $30{ }^{\circ} \mathrm{C}$ in the wet season; while the dry season ranges between $33{ }^{\circ} \mathrm{C}$ and $34{ }^{\circ} \mathrm{C}$. On average, the state is occupied by subsistence tuber, legume, and cereal farmers who depend solely on rain-fed agriculture; hence one can only imagine how climate change would impact on these farmers. The major occupation of the people of Kwara is largely agricultural-related as more than $70 \%$ of the population are farmers. Moreover, the plain to slightly gentle topography of Kwara State further makes it favorable for agricultural growth while other climatic patterns, vegetation, and the fertile soil make the state suitable for the farming of an extensive range of food crops such as cereals, cowpea, cassava, and tree crops, such as cashew and mango (Olanrewaju 2012). This review adopted Kwara State as a focus site because there are large number of cereal farmers in addition to favorable soil condition for production of grains such as rice, maize, millet, and sorghum, as this can favor low consumption of nutrient, low managerial procedure, as well as two planting seasons for rice and maize among others. 


\section{Agriculture and Cereal Production in Nigeria}

Nigeria is an agrarian country with a reasonable percentage of its population engaging in agriculture at subsistence level (Adhvaryu et al. 2019). Like most countries in Sub-Saharan Africa (SSA), farmers in Nigeria not only live in rural areas, but their agricultural holdings are generally minute with about two-thirds of the total production being practiced with the use of simple methods and the bushfallow system of cultivation. Agriculture, as practiced widely in Nigeria and other developing countries, is highly subjected to climate variability, and Nigeria's comprehensive range of climate differences supports a broad variety of the production of food crops (Olanrewaju 2012). Of the vast area of land for cultivation in Nigeria, cereals like sorghum, millet, rice, and corn are predominantly grown, but maize has overtaken the other traditional cereals such as wheat in terms of cultivation and popularity. Grains are rich in starches and contain substantial amounts of protein, as well as some fat and vitamins. They are essentially the world's staple food with over $70 \%$ of the world's harvested area producing a billion and a half tons of grains annually (Sokoto et al. 2016). Despite this, cereal production is set for a global increase with wheat, maize, and barley accounting for most of the rise in cereal production, while rice production is likely to maintain the increase as produced in 2018 (FAO 2019).

Rice is a starchy cereal that contains fiber, protein, vitamins, and minerals. It is consumed by more than half of the world's population (Rathna Priya et al. 2019) and is increasingly an important crop in Nigeria, with some species growing within 3 months. Africa cultivates about half of the 14 million metric tonnes of the annual global rice production (FAO 2019), while Nigeria is the largest producer and the leader in terms of consumption as well as importation in Africa. Nigeria's production has steadily advanced from two million metric tonnes to 8.0 million metric tonnes between 2008 through 2018 with the aim of reaching 18 million tonnes by 2023 (FAO 2019). This is due to rice policy reforms by the Federal Government of Nigeria who in its bid to eliminate rice importation enacted the anchor borrower's scheme that have paved way for proliferation of rice farming in the country (FAO 2019). Rice is not usually grown in isolation but with other crops such as sorghum, maize, and sweet potato. Initially, rice was noted as a luxurious food but has fast become a regular diet in every home in the country.

In Nigeria, maize is equally a significant food and feed crop which maintains an essential status for rural food security (Stevens and Madani 2016). Introduced to Nigeria in the sixteenth century, maize is the fourth most utilized cereal ranked below sorghum, millet, and rice (FAOSTAT 2014). Maize production in Nigeria is above ten million metric tons (Mundi Index 2018; FAO 2019), and it accounts for almost half of the calories and protein consumed in Eastern and Southern Africa (ESA), and one-fifth of the calories and protein consumed in West Africa. It is a significant source of carbohydrate, protein, iron, vitamin B, and minerals. Additionally, maize is essential in the cropping system of the small-scale Nigerian farmer and is frequently grown in mixture with other crops such as legumes or even cereals 
under traditional practice. This is not only because maize is relatively more affordable than other cereal crops, but it is also widely accepted in the region as edible plant (Sowunmi and Akintola 2010). Apart from millet, maize is the earliest grain that is harvested in any given season in Nigeria, hence offering respite to the usual food scarcity being experienced at such periods of the year while maize consumption is generally acceptable in various forms across the country (Mundi Index 2018).

It is now a common knowledge that farming activities, including cereal production, has put global populations at vulnerable climatic situations and many studies have evolved in the area (Adger et al. 2004). In Nigeria, the vulnerability to climate change can be seen in the overwhelming effects of recent climatic catastrophes in all the six geopolitical zones of the nation. The protracted droughts resulting in increased temperatures as currently being observed in the northern region and the late arrival and early cessation of rain (Apata et al. 2009) are manifestations of climate change impact. It is evidently clear that Nigeria is highly susceptible to the effect of climate change because of its wide $(800 \mathrm{~km})$ coastline which is prone to sea level rise and the various challenges related to the violent storms (Apata et al. 2009). In view of the foregoing, it has become expedient to assess the various adaptation strategies adopted by cereal farmers in Nigeria in order to better cope with the effect of climate change as well as serve as knowledge bridging gap for other farmers to leverage on. The next sections would highlight the effect of climate change on cereal production before drawing conclusion and recommendations that cereal farmers in the region where Kwara State is located can derive ideas from.

\section{The Impact of Climate Variability on Agriculture in Nigeria}

Climate variability may have an indirect influence on the goal of poverty alleviation in developing countries (Skoufias et al. 2011) as efforts at reducing the variations in climate help to increase agricultural yields which ultimately translate into better incomes for farmers and improved food security for the populace. This suggests that there might be efforts from development experts that could nurture linkages between climate vulnerabilities and development policies. Perhaps, such efforts and policy debates could eventually address the impact of climate change on agricultural-related practices. Falling incidences of climate variability will cushion the vulnerability levels of farmers (Skoufias et al. 2011), and the effect of climate change will normally be felt either directly or indirectly on all segments of the environment to include: socio-economy, water resources, food security, human health, ecosystems, coastal zones, and other related sectors. Fluctuations in precipitation and melting of glaciers are pointers to acute water shortages, soil erosion, and/or flooding (IPCC 2007), and these will absolutely affect agriculture produce. These climatic variations would inadvertently result in crop losses and low profits for farmers.

The steady increase in temperatures has necessitated an unavoidable shift in crop growing seasons for farmers in Nigeria and this has affected sufficient food availability and variations in the spread of disease vectors (Odjugo 2010; 
Apata et al. 2009). The variations in climate amplifies vulnerability of people to diseases through the disease-carrying vectors. Moreover, upsurge in temperatures can possibly result in increased rates of extinction of many species and habitats. This, in itself, is not favorable for the ecosystem, and in a like manner, pest and diseases migrate in response to climate change with serious consequences on agriculture and the entire planet (IPCC 2007; Earth Journalism Network 2016). Such irregular temperature patterns and movements of pests lead to erratic rainfall and sunshine patterns, thereby resulting in crops' instability. It is therefore apparent that there is a heightened (above global mean) warming rate on the lands as evaporative cooling has greatly reduced, and there exists a smaller thermal inertia when compared to those found in the oceans. Boko et al. (2007) reported a similar scenario for Nigeria where the authors stated that the warming rate in Nigeria was above the mean rate for Africa.

Extreme rainfall patterns and variations in Nigeria have become a serious production risk for agricultural production system that is largely rain-fed (Olayide et al. 2016). The rain-fed agricultural production system is vulnerable to seasonal variability which affects the livelihood outcomes of farmers who greatly depend on this system of production. Previous studies have also shown that varying temperature fluctuations, heat waves, relative humidity, and rainfall are bound to compromise agricultural production as substantial losses are observed in the yield of grains such as rice, millet, sorghum, and maize in Nigeria (Sokoto et al. 2016). It was similarly found that maize along with other cereals were more susceptible to climate variability with untold consequence on the yield (Bismark and Richard 2019). Similarly, it was found that yields and productivity of maize, millet, sorghum, and rice were negatively affected by unfavorable climatic conditions such as drought, excessive temperature, and low rainfall (Bamiro et al. 2020).

The complications that are linked to climate change are not the same across the country. Nigeria, for example, has a tropical climate with two precipitation regimes spanning the north and south of the equator. The north is typically low in precipitation and high in temperature while parts of southwest and southeast are distinguishingly lower in temperatures with high amount of rainfalls (Nkechi et al. 2016; Akande et al. 2017). Obviously, the northern climate can lead to grave ecological effects as demonstrated by aridity, drought, and desert encroachment in the north, and flooding and erosion in the South (Nkechi et al. 2016; Akande et al. 2017). It was further shown through vulnerability analysis that States in the north, especially north east and north west region, experience higher degrees of vulnerability to climate change than those in the south (Federal Ministry of Environment 2014; Madu 2016). These variations in the northern climate are further compounded by desertification, loss of the wetlands, with a disturbing decrease in the volume of surface water, flora, and fauna resources on land (Abdulkadir et al. 2017; Ebele and Emodi 2016). Interestingly, the Southwest and Southeast are relatively less vulnerable when compared to other parts of the country because of the eco-friendlier climate patterns as depicted by high precipitation and relative humidity. Although, despite the relatively less vulnerability of the southern region of the country, the South-South (Niger Delta region) is most susceptible, due to sea level rise, increased 
rainfall, coastal destruction, and flooding, which has resulted in the dislodgment of many settlements (Matemilola 2019).

The form of vulnerability to climate change usually corresponds with agronomic activities in a given location (Madu 2016). The argument here is that the northern regions of Nigeria, which coincidentally have higher degrees of rurality, are more vulnerable to climate change (Madu 2016). Hence, the adoption of existing and new technologies for adapting to climate change and variability is a high priority for most part of Nigeria. Evidence from secondary data has shown that farmers in the focus study site (Kwara State is located in the northern part of Nigeria) are already feeling the impact of climate change in many ways (Sokoto et al. 2016). The effect of climate change on cereals production is firstly noticeable in a sharp increase in production costs and reduced grains production while this translates into decreases in farmers' profit level (Sokoto et al. 2016). Ordinarily, the cost during production could have been minimal and relatively stable but for the heightened climate variabilities. In developing countries including Nigeria, climate variability and change do encourage heat and moisture stresses thereby adding to an already long list of existing problems (Earth Journalism Network 2016). How then are countries in the tropical regions able to deal with climate change impacts?

\section{Climate Change Adaptation Strategies for Cereal Farmers in Nigeria}

Adaptation is a method through which people make themselves better able to cope with an uncertain future. Adapting to climate change will therefore entail the application of efficient actions to lessen the adverse effects of climate change (or exploit the positive ones) by making the necessary modifications in order not to greatly feel the negative impact. Emerging countries, such as Nigeria, typically perceives industrialized countries as climes with reduced vulnerability and better adaptation strategies given that such regions are better able to realize the prospects in cold weather episodes and hence make calculated moves to strengthen their agricultural production (Achike and Onoja 2014). The international community through the UNFCCC are in serious deliberations to find an effective means to battle climate change. It therefore becomes pertinent for the international community to entrench, in their future decisions, processes that will assist developing nations with transfer of knowledge, technology, and financial resources to adapt at all levels and in all sectors.

Recent study offered that farmers in Africa use crop diversification to build resilience in the agriculture sector (Mango et al. 2018), although this method may not be a favorable means among certain other farmers. However, adaptation, regardless of whatever form it takes, is already considered a major and important integral part of any future climate change regime. Some of the known technologies in use for climate change variability and impacts include: crop diversification, the adoption of drought-tolerant and early-maturing varieties of crops, and planting of cover crops (Federal Ministry of Environment 2014; Achike and Onoja 2014). Studies have 
shown that farmers in Nigeria are being supported by government and other nongovernmental organizations to better adapt to climate change using these, as well as other methods to deal with climate change impact (Ifeanyi-obi and Nnadi 2014). In addition, relevant weather-related information and skills training that can enhance productivity can be offered by agricultural extension services (Akintonde and Shuaib 2016). Although the current irregularity of extension services in Nigeria is a limitation to the adaptation strategies (Akintonde and Shuaib 2016).

Other adaptation strategies used by farmers in SSA including Nigeria are: early planting of crops, a condition where crops would have enjoyed some reasonable amount of rain before it ceases. Rainy season, of the current year, in certain parts of Nigeria experienced a somewhat climate change, and this means that Kwara State, along with many other states in the country, did not enjoy rains in the months of July and August; supposedly, those months should have been the peak of rains when activities for farmers would normally climax. Thus, some farmers who tapped into the opportunity of early planting sowed particular grains in May/June (maize for instance) when there were initial heavy rains and those farmers were able to survive the drought occasioned by the lack of rains. However, most grains that would normally be planted later in July did not survive as this coincided with the cessation of rains in July and August and farmers lost their resources (monies, inputs, time, and energy).

Improved variety is another adaptation strategy in use in order to cope with climate change impact. Farmers now plant improved varieties that have high resistance to pest and diseases, requires low water, matures quickly, and with many more qualities. This strategy was found to be popular among cereal farmers in Nigeria. For example, close observation of rice farmers in Kwara State showed that they employed similar means to combat the impact of climate change within the region. Farmers now plant a locally crossbred rice variety from Kebbi State that germinates in 12 weeks while some other farmers are yet to tap into this innovation and are still growing older rice varieties that reach maturity in 4 months and above. The improved rice variety offers farmers the opportunity to cultivate and harvest rice twice in one growing season especially if such farmer leveraged on early planting strategy. The snag here, however, is that the improved seeds are more expensive, although on the flipside, farmers can produce seeds for the next growing season from the current one and can consequently save some costs in the next planting season. Again, this method may not work if prolonged rain shortages are experienced and there are no facilities for irrigation.

Crop rotation is also one of the strategies used by the farmers to assuage the impact of climate change. Farmers in SSA including Nigeria do not restrict themselves to sowing a mono-crop. They use grains and/or legumes to rotate across seasons. A farmer might plant corn along with other tuber crops such as cassava in one season, and then proceed to corn and cowpea in another season. There are times when farmers are able to predict what the next planting season would look like given their experiences from previous climate variation patterns and based on local climatic indicators, although their predictions may not always work as projected. For instance, farmers may envisage a favorable climate in the next growing season if 
temperatures in the current year are on the high and rains were too scanty. In such a situation, a farmer can predetermine which crops would offer more yield with high precipitation and less vulnerability to such weather. At the return of the rains in Kwara State at the tail end of August and beginning of September this year, farmers who have suitable lands hastened to plant soybean as this crop require less amount of rainfall and would normally germinate within 12 weeks when it is expected that the little rain that would fall in the remaining part of the season would be enough to see the crop to harvest in November. At some other times, farmers may rely on weather forecasts from relevant government agencies to determine what the forthcoming growing season would look like and adequately prepare for the crops that would thrive better in such weathers. Such information can also be leveraged on to determine what crops offer relative advantage over others, in order to make decisions as to the crops to rotate with the other in subsequent seasons. Such calculations help the farmers to plan better as well as make calculated risks that can translate to reduced climate change impacts.

In addition, farmers in Kwara State have also applied crop diversification as another adaptation strategy. For example, farmers have changed the crops grown on previously cultivated lands from a particular cereal crop to another due to climatic changes. Land that was previously being farmed for rice production because of abundance of water have now been converted to cultivation of maize and sorghum after such lands have lost their water content due to enduring droughts. The adaptation strategies adopted by cereal farmers in Kwara State are as seen in similar works where it was reported that crop diversification, adoption of drought-tolerant cultivars, early-maturing varieties of crops, and planting of cover crops are among the adaptation strategies being employed by farmers in Nigeria (Federal Ministry of Environment 2014; Achike and Onoja 2014).

Irrigation and drainage activities were also adaptive measures that farmers in Nigeria usually put into consideration during planting operations in order to secure water for plants during dearth periods (for example, as seen in northern Nigeria) and also mitigate the impact of flooding should the need arise, especially in the coastal southern region of Nigeria. This will reduce crop loss during insufficient and excessive rainfall like the full 2 months break earlier described in the current rainy season in Nigeria. Secondary data collected, observations and experiences from previous and current planting seasons showed that farmers in northern Nigeria had relied on strategies like direct interventions such as dike building to prevent flooding, large-scale relocation of farmers from excessively eroded areas, new crop selection, building of dams to expand irrigation, and crop rotation in order to curb the menace of climate change. Methods such as this would also ensure adequate yield of crops by farmers. Rice farmers in Kwara State, for instance, constructed make-shift dams at several points on their farms, where rain water is usually collected/deposited for use during dearth periods. Unfortunately, such water gets dried up whenever there is protracted or intense water shortage and farmers will sometimes need to walk long miles to areas where there are other sources of water (wells and boreholes) in order to irrigate their farms. The current prolonged lack of rains in Kwara State led to huge 
losses as farmers were not hitherto prepared and consequently could not cope well with the situation.

Another adaptation strategy adopted by cereal farmers in the focal site is cultivation of more agricultural areas. By this, it was observed that farmers chose not to wait until harvest period before they will discover heavy crop losses and/or damages; hence they became proactive by cultivating large expanse of lands to increase their productivity. Some farmers have increased their farm sizes through cultivation of more lands as this will make them generate more income as well as improve their livelihood. Interestingly, majority of farmers in Kwara State, like other parts of the country, do not own the lands where they farm. First of all, all lands in the country belong to the government and anyone who intends to take possession would have to seek the owner's (government) permission in the form of "registration of title" which attracts special charges. However, farmers have usually cultivated lands without the owner's permission and they are always ready to move to other expanse of lands whenever the rightful owners emerge to take over the lands. Farmers have occasionally recorded huge losses when such circumstances arise but they would rather take such risks as it has almost become a norm among them. It is only the large-scale commercial farmers that normally acquire the lands rightfully. Meanwhile, while farmers may be increasing their yields by cultivating more expanse of lands, this method is indirectly expanding land used for agricultural activities and will consequently increase their risks and exposure to climate change impacts.

Livelihood diversification is also one strategy being used by cereal farmers in the focus site. Some farmers who feel they could no longer cope with the climate change impacts have decided to change the means/source of livelihood. Some of the cereal farmers in Kwara State have attempted diversification to nonfarming activities as adaptation strategies while discouraging youths, who are becoming more interested in white collar jobs, from participating in agricultural activities. Hence, though sadly, some of the farmers have boycotted farming for artisan jobs as well as bicycle riding jobs in order to sustain their families.

\section{Conclusion}

Agricultural activities play a major role in the development of any country, and the effect of climate change on agronomic activities cannot be underrated due to its direct impact on agricultural production. Climate change may be a global issue but its effects will automatically differ between geographical regions. While food production in some areas may suffer from extreme weather and temperatures, farming in other regions might benefit from longer growing seasons and warmer climates. Early planting, crop diversification, planting of improved variety, irrigation and drainage practices, crop rotation activities, and cultivation of more agricultural land areas were the adopted strategies used in the focus site to help farmers cushion the impact of climate change. Therefore, farmers need to continue to adopt those strategies to combat this situation, in order to keep sustaining their livelihoods. 


\section{Recommendations}

Based on observations and inferences highlighted, cereal farming, in Nigeria as a whole and particularly in the area of focus, would be enhanced if these recommendations are taken:

1. There is a need for meteorological agencies (for example, Nigerian meteorological agency - NiMet) to widen their scope and expand their methodology to ensure that small-scale farmers benefit from their forecasts, in order to reduce farm losses due to unfavorable weather episodes. This will make farmers to predetermine the crops and time to plant.

2. Rain-water collection systems can be made available by collaborative efforts of the farmers, while government and other stakeholders serve as buffer during dry season and early cessation of rainfall. This will help in situations like the one experienced this current season by farmers in Kwara State where farmers became helpless as a result of unexpected shortage of rains.

3. The public sector (government) can further encourage small-scale farmers by instituting favorable policies that will stimulate farmers to remain on the fields as well as enhance them to better cope with unfavorable climatic conditions. Such policies, like fertilizer subsidy and those enacted for increased rice production, would reduce cases of livelihood diversification where youths are seen to migrate to cities for alternative jobs.

4. Provision of communal irrigation facilities (every problem must not be solved at the instance of government) for use in times of water scarcity to avoid food shortages for the populace. This will also reassure farmers that their efforts would not be a waste and the fear of unexpected huge losses on their part can be allayed.

\section{References}

Abdulkadir A, Lawal MA, Muhammad TI (2017) Climate change and its implications on human existence in Nigeria: a review. Bayero J Pure Appl Sci 10(2):152-158. https://www.ajol.info/ index.php/bajopas/article/viewFile/170772/160195

Achike AI, Onoja AO (2014) Greenhouse gas emission determinants in Nigeria: implications for trade, climate change mitigation and adaptation policies. https://www.journalijecc.com/index. php/IJECC/article/view/27273/51196

Adger WN, Brooks N, Bentham G, Agnew M, Eriksen S (2004) New indicators of vulnerability and adaptive capacity. Tyndall centre technical report, no 7. Tyndall Centre for Climate Change Research, University of East Anglia, Norwich

Adhvaryu A, Nyshadham A, Tamayo J (2019) Managerial quality and productivity dynamics. Harvard Business School. Working paper 19-100

Ajadi BS, Adeniyi A, Afolabi MT (2011) Impact of climate on urban agriculture: case study of Ilorin City, Nigeria. Global J Human Soc Sci 11(1)., Type: Double Blind Peer Reviewed International Research Journal Publisher: Global Journals Inc. (USA)

Akande A, Costa AC, Mateu J, Henriques R (2017) Geospatial analysis of extreme weather events in Nigeria (1985-2015) using self-organizing maps. Adv Meteorol. https://doi.org/10.1155/ 2017/8576150

Akintonde JO, Shuaib L (2016) Assessment of level of use of climate change adaptation strategies among arable crop farmers in Oyo and Ekiti States, Nigeria. J Earth Sci Clim Chang 7:369. 
https://www.omicsonline.org/open-access/assessment-of-evel-of-se-of-climate-change-adapta tion-strategiesamong-arable-crop-farmers-in-oyo-and-ekiti-states-nigeria-2157-7617-1000369. php?aid $=80244$

Apata TG, Samuel KD, Adeola AO (2009) “Analysis of climate change perception and adaptation among arable food crop, farmer in South Western Nigeria" Contributed paper at the International Association of Agricultural Economists 2009 conference, Beijing

Bamiro O, Adeyonu A, Ajiboye B, Solaja S, Sanni SO, Faronbi O, Awe T (2020) Effects of climate change on grain productivity in Nigeria (1970-2014). IOP conference series. Earth Environ Sci 445:012058. https://doi.org/10.1088/1755-1315/445/1/012058

Bismark MB, Richard K (2019) Climate Variability Effect on Food Crop Yield among the Smallholder Farmers in Lower Off in River Basin, Ghana. Journal of Agriculture and Environmental Sciences 8(2):66-74. Published by American Research Institute for Policy Development. https://doi.org/10.15640/jaes.v8n2a9

Boko M, Niang I, Nyong A, Vogel C, Githeko A, Medany M, Osman-Elasha B, Tabo R, Yanda P (2007) In: Parry ML, Canziani OF, Palutikof JP, van der Linden PJ, Hanson CE (eds) Africa climate change: impacts, adaptation and vulnerability. Contribution of working group II to the fourth assessment report of the intergovernmental panel on climate change. Cambridge University Press, Cambridge, UK, pp 433-467

Earth Journalism Network (2016) Introduction to climate change. Available at: https:// earthjournalism.net/resources/introduction-to-climate-change

Ebele NE, Emodi NV (2016) Climate change and its impact in Nigerian economy. J Sci Res Rep 10(6):1-13. http://www.journaljsrr.com/index.php/JSRR/article/view/21917/40737

FAO (2015) Climate change and food systems: global assessments for food security and trade. In: Elbehri A (ed) A publication of the Food and Agricultural Organization, Rome. Avaliable at: http://www.fao.org/3/a-i4332e.pdf

FAO (2019) Food outlook - biannual report on global food markets. Rome. Licence: CC BYNC-SA 3.0 IGO

FAOSTAT (2014) The state of food and Agriculture, investing in Agriculture for a better future. http://Faostat.fao.org

Federal Ministry of Environment (2014) United nations climate change Nigeria. National Communication (NC). NC 2. 2014. https://unfccc.int/sites/default/files/resource/nganc2.pdf

Ifeanyi-obi CC, Nnadi FN (2014) Climate change adaptation measures used by farmers in southSouth Nigeria. J Environ Sci Toxicol Food Technol 8(4). https://pdfs.semanticscholar.org/a63d/ 22bf8b8ebde892a7c9d761ee1653e0e11df6.pdf

IPCC (2007) Climate change 2007: impacts adaptation and vulnerability. In: Contributions of working group II to the fourth assessment report of the intergovernmental panel on climate change. Cambridge University Press, Cambridge, UK

Madu IA (2016) Rurality and climate change vulnerability in Nigeria: assessment towards evidence based even rural development policy. Paper presented at the 2016 Berlin conference on global environmental change, 23-24 May 2016 at Freie Universität Berlin. https://pdfs. semanticscholar.org/508b/94cab07b84a703b44eca1089326cc98d7495.pdf? ga $=2.154518008$. $112403230.1572433568-162569160.1557482164$

Mango N, Makate C, Mapemba L et al (2018) The role of crop diversification in improving household food security in central Malawi. Agric Food Sec 7:7. https://doi.org/10.1186/ s40066-018-0160-x

Matemilola S (2019) Mainstreaming climate change into the EIA processing Nigeria: perspectives from projects in the Niger Delta region. Climate 7(2):29. https://doi.org/10.3390/cli7020029

Mboera L, Mayala B, Kweka E, Mazigo H (2012) Impact of climate change on human health and health systems in Tanzania: a review. Tanzan J Health Res 13. https://doi.org/10.4314/thrb. v13i5.10

Mundi Index (2018) Nigeria country profile. Available at: https:/www.indexmundi.com/nigeria/ agriculture products.html

Nkechi G, Onah N, Ali A, Eze E (2016) Mitigating climate change in Nigeria: African traditional religious values in focus. Mediterr J Soc Sci 7(6):299-308. https://www.mcser.org/journal/ index.php/mjss/article/view/9612 
Odjugo PAO (2010) Adaptation to climate change in the agricultural sector in the semi-arid region of Nigeria. Paper presented at the 2nd international conference: climate, sustainability and development in semi-arid regions, Fortaleza-Ceará, Brazil, August 16-20, 2010

Olanrewaju RM (2009) Climate and the growth cycle of yam Plant in the Guinea Savannah Ecological Zone of Kwara state, Nigeria. J Meteorol Clim Sci:43-48

Olanrewaju RM (2012) Effect of climate on yam production in Kwara State, Nigeria. Environmental Issues, Department of Geography and Environmental Management, University of Ilorin, Ilorin 3(1):30-34

Olayide OE, Kow Tetteh I, Popoola L (2016) Differential impacts of rainfall and irrigation on agricultural production in Nigeria: any lessons for climate-smart agriculture? Agric Water Manag 178:30-36. https://doi.org/10.1016/j.agwat.2016.08.034. ISSN 0378-3774. Available: http://www.sciencedirect.com/science/article/pii/S0378377416303286

Omumbo JA, Lyon B, Waweru SM, Connor SJ, Thomson MC (2011) Raised temperatures over Kericho tea estates: revisiting the climate in the east African highlands malaria debate. Malar J $10: 2$

Rathna Priya T, Eliazer Nelson ARL, Ravichandran K (2019) Nutritional and functional properties of coloured rice varieties of South India: a review. J Ethn Food 6:11. https://doi.org/10.1186/ s42779-019-0017-3

Reuben J, Barau AD (2012) Resource use efficiency in yam production in Taraba state, Nigeria, journal of agricultural science. Kamla-Raj 3(2):71-77

Skoufias E, Vinha K, Conroy HV (2011) The impacts of climate variability on welfare in rural Mexico, policy research working paper 5555. World Bank, Washington, DC

Sokoto M, Tanko L, Abubakar L, Dikko A, Abdullahi Y (2016) Effect of climate variables on major cereal crops production in Sokoto state, Nigeria. Am J Exp Agric 10:1-7. https://doi.org/10. 9734/AJEA/2016/20020

Sowunmi FA, Akintola JO (2010) Effect of climatic variability on maize production in Nigeria. Res J Environ Earth Sci 1:19-30

Stevens T, Madani K (2016) Future climate impacts on maize farming and food security in Malawi. Sci Rep 6:36241

Zoellick RB (2009) A climate smart future, the nation newspapers. Vintage Press Limited, Lagos, p 18

Open Access This chapter is licensed under the terms of the Creative Commons Attribution 4.0 International License (http://creativecommons.org/licenses/by/4.0/), which permits use, sharing, adaptation, distribution and reproduction in any medium or format, as long as you give appropriate credit to the original author(s) and the source, provide a link to the Creative Commons license and indicate if changes were made.

The images or other third party material in this chapter are included in the chapter's Creative Commons license, unless indicated otherwise in a credit line to the material. If material is not included in the chapter's Creative Commons license and your intended use is not permitted by statutory regulation or exceeds the permitted use, you will need to obtain permission directly from the copyright holder. 